\title{
INTERNATIONAL AND LATVIAN LEGISLATION ON SPORT
}

Ieva Opolska ${ }^{1}$, Mg.oec.; Liga Proskina², Dr.oec.

${ }^{1,2}$ Faculty of Economics and Social Development, Latvia University of Life Sciences and Technologies

\begin{abstract}
A healthy nation is the cornerstone of a country. Sports as a growing economic and social phenomenon greatly conduce the achievement of strategic goals of the European Union as pertains to solidarity and well-being. At the international level, the Latvian sport sector is coordinated by International Olympic Committee, The World Anti-Doping Agency, Court of Arbitration for Sport; European Union: European Sports Charter. Programmes and activities for sport development are Erasmus + Sport and European Sports Week. The main sports legislation in Latvia is the Sport Law, which defines the general and legal foundations of sport organization and development, the mutual relations of the sports organizations, state and local government institutions and the basic tasks in the development of sport, and the fundamentals of financing the sport, as well as the principles that are significant when participating in the international sport movement. The sport sector is coordinated and managed by associations. The sport sector plays an important role in the development of regions, as physical activity affects public health. Main conclusions:it is inferred that the sports legislation is too general and non-specific. It has to be improved in order to ensure the development of sports industry. The current sports industry administration in Latvia is insuffcient to manage the industry successfully and achieve the goals set by the guidelines. The authors draw attention to the consideration that the sports administration and budget would have to pursue the higher achievement of volumes.
\end{abstract}

Key words: sports law, sports legal, sports organisations, Latvian sports industry, sports economics. JEL code: available on: K10.

\section{Introduction}

Sport is one of the sectors of the national economy that promotes not only a healthy lifestyle, but is also a business which is taxed and money goes in the state budget. By sports we understand all kinds of individual or organised activities for person's physical and mental health and fitness, as well as achievements in sports competitions. Each country takes care of the health and welfare of its nation. The development of the national economy can be facilitated by the occupation of the population by sport, as well as the organization of important sports events (Research on the Impact of Large-Scale Sports Events on the Latvian Economy, 2016). Since the development of sports organizations and the quality of their activities in the regions have a major impact on the social development of the population (improvement of health, socialization, patriotism, prevention of social risks), as well as growth of economic indicators (increase of working capacity, jobs opportunities, tax contributions, attractiveness of the region for investors), it is important to study the legislation and its impact on the sport sector.

Lifestyle and behavior are factors affecting society's health. The most important public health problems are non-communicable diseases. The main behavioral factors contributing to the development of these diseases are unhealthy diet, insufficient physical activity and addictive substances and processes (Public Health Policy Guidelines 2014-2020). According to the Eurobarometer survey, $44 \%$ of the population in Latvia do not have physical or sporting activities, while the EU average is $39 \%$. It was also found that at least 1-2 times a week in Latvia, only $28 \%$ of the population is engaged in physical or sporting activities, while the EU average is $40 \%$ (Eurobarometer, 2010). In 2002, the World Health Organisation deemed "Physical Activity" the theme of World Health Day. Since that time, April 6th is celebrated as the World Day for Physical Activity. This is an excellent example of a global initiative aimed at promoting health through physical activity across populations (Who.int, 2019).

${ }^{1}$ Ieva Opolska, ieva.opolska@gmail.com, +371 26550385

2 Liga Proskina, liga.proskina@llu.Iv, +371 28206624 
Doping, match-fixing and violence are the problems what demand attention. Legal and regulatory frameworks define the frames and guidelines of the sports industry (all sports related products and organisations). And due to the globalization of sports activities, this analysis maintains that the role to be played by public international law is one of the key elements of this process.

This article tries to show, sports importance in humans life and social economics, what laws and organizations regulate the Latvian sport industry and how it affects. In our study, we provide a literature review of sports law and sports management organizations.

In view of the extensive research topic, the general acts of the sport sector will be dealt with in general terms.

The aim of article is to review and analyse international and Latvian legislation on sport, to review and analyse recent researches on the sports law in context social economics.

To achieve the aim, the following specific tasks were set:

1) To give insight into the links between the sport industry and socio-economic indicators; 2) give insight into the situation in the field of Latvia sports legislation, placing a particular focus on sports managing organisations; 3 ) to analyse the International legal and regulatory frameworks on sports sector; identify the role of sport in the EU; 4) to analyse the Legal framework on Sport in Latvia.

The research employs qualitative research: the logical constructive method, the monographic method, the method of analysis and synthesis. The research is based on scientific theoretical literature, scientific articles and the legal framework analysis of the Republic of Latvia, International sports industry and Europenian Union framework and programms. By applying various research methods, documents focusing on sport, sports law and sports organizations were analysed. The authors gathered studies and literature about the: Sport as an important factor in human development; International legal and regulatory frameworks on sports sector and Sports role in EU; Legal framework on Sport in Latvia.

\section{Research results and discussion}

The goal of the Latvian state is a healthy and active young generation, promoted by regular physical activity. The goal of the Latvian state is a healthy and active young generation, promoted by regular physical activity. DNB Latvian Barometer study conducted in 2014, people aged 18-74 have acknowledged that one of the most important things to do for a healthy lifestyle and to maintain health is regular physical activity and sports (it considers $41 \%$ of respondents). However, people's answers also suggest that things that are considered to be most important in maintaining a healthy lifestyle are far from common in everyday practice. Only $29 \%$ of respondents actually engage in regular physical activity and sports (DNB Latvian barometer, 2014). According to the guidelines developed by the World Health Organization, a sufficient amount of physical activity is 150 minutes a week.

The Ministry of Education and Science (MES) shall implement the State administrative functions in the sports sector: implement a unified State policy; develop draft laws and regulations; implement purposeful international co-operation and ensure Latvian representation in international sports organisations; perform other functions and tasks specified in laws and regulations. The Law on Sports provides for the competencies of other ministries in the domain of sports, intended for implementation in cooperation with the Ministry of Education and Science. The structures involved in the development of the sports industry are: the Ministry of Welfare, the Ministry of the Interior, the Ministry of Defence, the Ministry of Justice and the Ministry of Health. The competencies of municipalities and employers in the domain of sports are also allocated separately. Municipal 
competencies determine the rights of municipalities as pertains to the promotion of healthy lifestyle and development of sports within the administrative territories thereof, as well as stipulate the municipal funding of the licensed sports education programs implemented by accredited sports education institutions subordinate to the respective municipalities (Law on Sports). Competencies of employers include promotion of their employees' engagement in sports activities; apart from that, employers have the right to organise sports competitions for employees and ensure their participation in athletic competitions held by other persons or entities (Sports law). Being aware of the competences of the state and local governments in the field of sport, it is important to do research in the field of sports legislation.

\section{International legal and regulatory frameworks on sports sector}

Sport as a social practice is highly rule-bound. Individual sports are regulated by their own dedicated constitutional rulebooks and adjudication machinery. The volume of rules varies between different sports. Some are particularly multifarious. Rules in sport exist for both its organisation and playing. The interaction of sports' internal rules and the influence of the law are also important; the internal rules of sport need to be examined before the role of the law in sport can be fully evaluated. (Gardiner S., O' Leary J., Welch R., 44)

International sports federations are the bodies in charge of the organization of sports activities at the international level. International Olympic Committee (IOC), the World Anti-Doping Agency (WADA), and international sports federations have undeniable power (Oxford bibliographies, 2019). From a legal perspective, they are private associations created in accordance with private domestic law whose members are national sporting associations that have been admitted into membership. Their task is to organize and coordinate the particular sport and also organize international competitions and events.

The emergence of private mechanisms of settling sports disputes through national and international sports arbitration tribunals being the Court of Arbitration for Sport (CAS) the supreme instance of this system seeks to avoid the intervention of national courts (Oxford bibliographies, 2019).

Each day, the development of technology and medication brings about new substances that may help boost one's athletic performance. In order to maintain adherence to fair play principles and make sure that the fastest, strongest and best ones win, a potent organisation and system is required to govern the use of restricted substances.

Doping is cheating (Green, 2014) in the sense that it is a breach of the rules of sport. Sports regulations provide sanctions against all these different types of cheating. Most forms of cheating are punished as part of the game, race or tournament although some may result in some postcompetition sanctions such as a fine. The reality of elite sporting competition is that cheating in one form or another is relatively commonplace; however, none carry the stigma nor result in such punitive and emotive reaction as doping cheats (Gardiner S., O' Leary J., Welch R., 364). WADA key activities include scientific research, education, development of anti-doping capacities, and monitoring of the World Anti-Doping Code (Code) - the document harmonizing anti-doping policies in all sports and all countries.

CAS gained popularity thanks to the growing number of cases registered therewith. Just 2 cases were filed in 1989, as distinct from 599 cases in 2016. (Court of Arbitration for Sport). CAS is used for adjudicating disputes between private individuals through the use of national and international sports arbitration tribunals. This agency tries to avoid the intervention of state courts (Oxford 
bibliographies, 2019). It is subordinate to the administrative and financial institution International Sports Arbitration Court Council (IAKS). CAS employs its own professional regulations (Code of Sports-related Arbitration), with the latest version thereof effective since January 1, 2019. These regulations provide for an independent regimen and govern just about every practical aspect of the arbitration process (Code of Sports-related Arbitration, 2018).

Sports industry is indeed a broad one, and it keeps on developing with each passing year. Are the legal acts in effect as of today capable of addressing the entire range of issues in the industry? The author suggests that the answer is no, as these are written generally and only provide general answers. These documents have been developed for traditional sports, failing to consider the rapidly increasing popularity of e-sports that can be observed at the moment. Is the law going to be capable of governing this branch of the industry as well?

Sports role in the EU. Sport and exercise are an integral part of life for millions of Europeans and a key feature of the EU's new Erasmus+ programme, which promotes cooperation, dialogue and participation. The EU supports cooperation between policymakers and dialogue with sports organisations, to promote the positive values associated with sport and tackle challenges (EU, 2018). European Sports Charter (adopted by the Committee of Ministers on 24 September 1992 at the 480th meeting of the Ministers' Deputies and revised at their 752nd meeting on 16 May 2001) is the major document and regulation is sports in EU. "Sport" means all forms of physical activity which, through casual or organised participation, aim at expressing or improving physical fitness and mental wellbeing, forming social relationships or obtaining results in competition at all levels (Sports Charter).The Charter complements the ethical principles and policy guidelines set out in: the European Convention on Spectator Violence and Misbehaviour at Sports Events and in Particular at Football Matches; the Anti-Doping Convention (Council of Europe).

Europeanin Commission (EC) on 2011 opened funding programme "Erasmus+" to support education, training, youth and sport in Europe. "Erasmus+" funds partnerships between sports organisations, non-profit events and research to strengthen policymaking. Also, the EC is in charge for "European Week of Sport” event which is taking place right across Europe, aims to encourage Europeans to be active in their everyday lives and European Union work plan for sport (2014-2017). Under the plan, the Commission organises forums of experts who meet to find solutions to problems facing European sport.

\section{Legal framework on sport in Latvia}

In Latvia there are: 781 sports organisations, 1223 sports halls, 49 stadiums, 92 sports schools and clubs, 55 mountain skiing tracks, and 81 public swimming pools (Sports, Latvia.eu) which are governed by the laws of Latvian sports. In Latvia sports sector is divided into several levels. The main authority of the sports sector structure is the Saeima of the Republic of Latvia, the sports subcommittee. The Sports Subcommittee was set up to deepen the work of the Education, Culture and Science Commission in the field of sports. After that, the Cabinet of Ministers has the highest influence.

The National Sports Council of Latvia is a public advisory body that participates in the development of a state sports policy, promotes sports development and co-operation in the field of sports, as well as decision-making on sports related issues (MES). The composition of the National Sports Council of Latvia was approved in 2016 by the Cabinet of Ministers Order No. 169 "On the composition of the National Sports Council of Latvia". 
In Latvia, the development of sport is coordinated and regulated by the Ministry of Education and Science, under the authority of sports organizations, federations, associations and sports clubs. The goal of the Latvian national sports policy is the formation of healthy, physically and mentally highly developed personalities. The general legal basis of sports organisation and development in Latvia is determined by the Sports Law. The Ministry of Education and Science is the state administration institution responsible for the area of sports.

The direction of sports policy can be divided into four sections: Children and youth sports; Sports for everybody; High achievement sports; Sports for people with disabilities. The MES influence management consists of: State Secretary, Deputy State Secretary, Director of Sports Department and Sports Department. The interests of clubs and federations are represented by associations - nongovernmental organizations. These are: Latvian Sports Federation Council, Latvian Olympic Committee and Latvian Paralympic Committee (MES).

Consolidation in the form of structures to represent common interests enhances the public and political influence of the organisation. Non-government organisations are mainly non-profit associations incorporated for representing a specific sport and conducing its development.

Legislation in the sports sector. The main sports legislation in Latvia is the Sport Law (adopted on October 24, 2002), which defines the general and legal foundations of sport organization and development, the mutual relations of the sports organizations, state and local government institutions and the basic tasks in the development of sport, and the fundamentals of financing the sport, as well as the principles that are significant when participating in the international sport movement. However, without Sport Law, there are issues of importance to the sports industry are addressed both in international law and in policy planning documents for other sectors and are: Latvian National Development Plan 2014-2020, Public Health Guidelines 2011-2017, Youth Policy Guidelines 2009-2018, Regional Policy Guidelines 2013-2019, the European Sport Charter, the Olympic Charter, the Code of Conduct for Sports, the White Paper on Sport and others.

The purpose of Sports Law is to specify the general and legal basis for sports organisation and development, mutual relationships of sports organisations, State and local government institutions and basic tasks in sports development, and the basis for the financing of sport, as well as the principles that shall be observed when taking part in the international sports movement (Sports Law).

The Law on Sports bestows a number of competencies in sports on municipalities. One of these competencies is to promote the establishment and operation of sports organisations, including sports clubs. Sports organisations are sports clubs, sports federations and other institutions provided for by this law. A sports federation may represent several sports or areas of operation. A sports federation may manage and coordinate activities in the respective sport or area of operation at the national level or represent its country with the respective international sports organisation, if such federation is recognised in accordance with the procedure provided for by this law. Only one federation may be recognised in a specific sport or area of operation.

The authors have studied the legislative regulation of how a federation is established and which criteria have to be met in order for it to be recognised in Latvia and internationally. It leads to the inference that anyone willing to develop a new sport in Latvia may establish a federation. The status of a recognised federation may also be achieved by means of fulfilling the requirements of the Latvian Sports Federations Council (LSFP) and the Latvian Olympic Committee (LOK).

Article 12 of the Law on Sports contains provisions in respect of the maintenance and usage of sports camps, which prioritise the need to provide sports opportunities to the population. The Cabinet 
of Ministers can assign the status of a national sports facility to a sports camp in accordance with the procedure provided for by the Law on the Status of a National Sports Facility.

The law stipulates the way of raising financial resources for sports. These are comprised of government funds, municipal funds, funds provided by individuals and legal entities, funds of sports organisations and transfers of international sports federations. Government budget funds are allocated to sports in accordance with the annual government budget law The law stipulates that the main priority of the government is to support children's and youth sports, thus emphasising the future of national sports Paragraph 6, article 13 says that the government provides funds for the preparation and participation of national athletic games teams in qualifying and final tournaments of European and World Championships and the Olympic Games in accordance with the procedure provided for by the Cabinet of Ministers; however, there are No separate provisions in respect of government funding or support of individual sports or the procedure to be followed in respect thereof.

The law determines the procedure for awarding cash rewards for excellent achievements in sports. These can be awarded to Latvian athletes, their trainers and sports service personnel. According to the Order of the Cabinet of Ministers No. 680 of 19 December, 2018 on high achievements, 59 athletes and their preparation team members were rewarded. In order to ensure the payment of cash prizes totalling to 1.2 M EUR, the Ministry of Finance was asked to allocate an amount of EUR 1 240050 to the Ministry of Education and Science from the government budget program 02.00.00 "Funds for unforeseen expenses" (Latvijas Vestnesis, 2018).

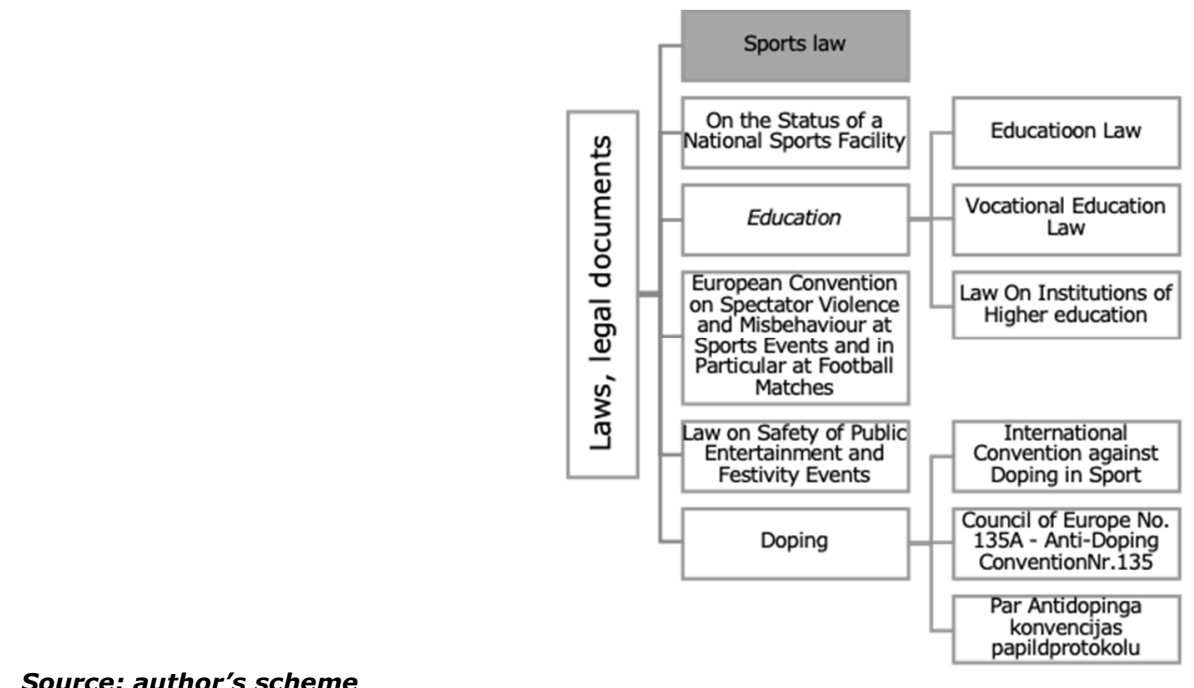

Source: author's scheme

Fig. 1. Sports legislation in Latvia

In order to study the institutional system and legal acts in the sports industry, the author has developed an scheme (Fig. 1) schematically depicting the laws governing the sports industry.

The Law on Sports determines the procedure for organising sports events. The main document of a competition is the Statute of the Competition, which contains the specified information about the competition. In addition to the provisions of the Law on Sports, another regulatory act to be mentioned is the Law on the European Convention on Spectator Violence and Misbehaviour at Sports Events and in particular at Football Matches. The goal of this law is to prevent and control the problem of spectator violence and misbehaviour at sports events (European Convention on Spectator Violence and Misbehaviour at Sports Events and in Particular at Football Matches). The goal of the Law on Safety of Public Entertainment and Festivity Events is to ensure unimpeded and safe occurrence of public events. This is intended to make sports events open and safe for the public. The law has been passed by the Saeima on 16 June, 2005 (Law on Safety of Public Entertainment and Festivity Events). 
Another essential regulatory act is the International Convention against Doping in Sport, which contains provisions that promote and coordinate international cooperation for restricting doping in sports, preventing doping in sports and fighting doping in sports for the purpose of eliminating it completely (International Convention against Doping in Sport).

Regulations of the Cabinet of Ministers are the primary sources of law in Latvia. The Cabinet of Ministers may issue legislation in the form of regulations (Latvian: noteikumi) in the following cases: 1. on the basis of an authorization laid down by statute; 2 . to approve an international agreement or draft thereof, denounce an international agreement or suspend its operations, unless the Constitution or the law provides otherwise; 3. if necessary for the application of European Union legislative acts and if the issue in question has not been regulated by statute; these regulations may not impinge on the fundamental rights of private individuals (E-justice, 2016).

Strategic planning documents concerning sports. The Sports Policy Guidelines for the period of 2014 to 2020 (referred to hereinafter as the Guidelines) is a medium-term policy planning document that determines the national policy in sports for the following seven years - two Olympic cycles. The Guidelines encompass the core principles of sports policy, its goals, directions, target groups and priorities, lines of activities and objectives for attaining the goals and solving the problems of sports policy (Sports Policy Guidelines for 2014-2020, 2013), (Sports Policy Guidelines for 20142020 - Summary, 2013). The government of Latvia seeks to make the new generation healthy and active, promoting it through regular physical activities. According to the Sports Policy Guidelines and in the author's opinion, the support and promotion of sports and physical activities for different age groups in Latvia is insufficient as of today. The driving motive of the sports policy defined by the Guidelines is "Sports make the quality of life". Directions of the sports policy defined by the Guidelines: 1) children's and youth sports, 2) sports for everyone, 3) the sport of records, 4) adjusted sports. Within the boundaries of these directions, development of the "Children's and youth sports" and "Sports for everyone" lines of sports policy is deemed a priority. The goal of sports policy defined by the Guidelines is to increase the percentage of inhabitants of Latvia who go in for sports or practice physical or athletic activities No less than 1-2 times a week (Sports Policy Guidelines for 2014-2020informative part, 2013).

The first goal defined by the Sports Policy Guidelines for the period of 2014 to 2020 is to promote physical activity of the population (especially children and young people). In the author's opinion, an essential contribution to the attainment of this goal would be to study the reasons that have been preventing children and young people from having sufficient physical activity until now.

The sources of funds intended for the implementation of the Guidelines are comprised of government and municipal budget funds, as well as private and other raised funds (including those provided by international sports organisations) (Sports Policy Guidelines for 2014-2020informational section 2013).

\section{Conclusions, proposals, recommendations}

The history of Latvian sports as well as the history of Latvian people was full of search of its true self and struggles for the independency, what of course has a reflection in Latvian legislative acts on sports and explains its possible imperfections.

Promoting a healthy and active lifestyle among different groups of society and organisation of public sports events is the key activities for healthy and sporty society.

This paper makes several central points. 1. Sports are a growing economic and social phenomenon that greatly conduces the achievement of global and national strategic goals as pertains 
to solidarity and well-being. 1. It is inferred that the sports legislation is too general and non-specific. It has to be improved in order to ensure the development of sports industry. 3. The sports industry in Latvia is organised and overseen by the Sports Department of the Ministry of Education and Science (currently employs 7 people). The most important administrative bodies are the Latvian Sports Federations Council and the Latvian Olympic Committee. In the authors' opinion, this is not enough to manage the industry successfully and achieve the goals set by the guidelines. The authors draw attention to the consideration that the sports administration and budget would have to pursue the higher achievement of volumes.

In the authors' opinion, the current administration would have to review priorities and develop the in adherence to the following principles: Maximally conduce the increase in physical activities of the population. The means to achieve this objective would be to increase the overall time of physical education classes in schools, train teachers and trainers, support record athletes and teams; It is also essential to broaden the opportunities for people to go in for sports (both paid and free services) and build sports facilities that could house international competitions and used in a multi-functional manner, in particular, also for cultural events; The sports management, legislation and financing system would have to be improved considering the current situation and future trends.

In conclusion, there is a wider implication that can be drawn from this study material.

\section{Bibliography}

1. Anti-Doping Rule Violations (ADRVs) Report 2014 (2016). Available: https://www.wadaama.org/sites/default/files/resources/files/wada-2014-adrv-report-en.pdf

2. Charker, A. N. (1999). Study on National Sports Legislation in Europe. Strasbourg: Council of Europe Publishing.

3. Christiansen, N. V., Kahlmeier, S., \& Racioppi, F. (2014). Sport promotion policies in the European Union: Results of a contents analysis. Scandinavian Journal of Medicine and Science in Sports, 24(2), 428-438. https://doi.org/10.1111/j.1600-0838.2012.01500.x

4. Code of Sports-related Arbitration (2017): Court of Arbitration for Sport. Available: http://www.tascas.org/fileadmin/user_upload/Code_2017_FINAL_en_.pdf

5. Education, Audiovisual and Culture Executive Agency (2017), Erasmus + Sport. Available: http://eacea.ec.europa.eu/home/erasmus-plus/actions/sport

6. European Union (2007). European Commission White Paper on Sport, COM/2007/0391 final http://www.aop.pt/upload/tb_content/320160419151552/35716314642829/whitepaperfullen.pdf

7. Gardiner S., O' Leary J., Welch R., Sports Law. Forth edition. (2012) pp.364-392.

8. Green S. 'Cheating' (2004) 23(2) Law \& Phil., 135-187; Beloff, M. 'Fair play - is there still room for the Corinthian spirit in sport?' (2009) pp. 34-44.

9. Informacija par valsts budzetu un ta sadalijumu 2018. gada (2018). Ministry of Education and Science. Available: https://www.izm.gov.lv/Iv/sports/sporta-budzets/informacija-par-valsts-budzetu-un-tasadalijumu-2018-gada.

10. International Sports Law (2019), Oxford bibliogrphies. Available: http://www.oxfordbibliographies.com/view/document/obo-9780199796953/obo-9780199796953-0073.xml

11. Media Center. World Health Organization. Available: https://www.who.int/mediacentre/news/releases/2003/pr15/en/

12. Of the Committee of Ministers to Member States on the Revised European Sports Charter. (2001) Council of Europe, Committee of Ministers. Retrieved: https://rm.coe.int/16804c9dbb

13. Par naudas balvu pieskirsanu par izciliem sasniegumiem sporta (2018). Latvijas Vestnesis: Nr. 250 (6336).

14. Parrish R. (2013). Sports, law and policy in the Europenian Union. pp 180-182

15. Public Health Policy Guidelines 2014-2020. Available: https://likumi.Iv/ta/en/en/id/269591-on-the-publichealth-policy-guidelines-2014-2020

16. Research on the Impact of Large-Scale Sports Events on the Latvian Economy, IZM, 2016

17. Sport and Physical Activity. Special Eurobarometer. European Commission. Retrieved: http://ec.europa.eu/commfrontoffice/publicopinion/archives/ebs/ebs_334_en.pdf

18. Sport. European Commission. Available: https://ec.europa.eu/info/topics/sport_en

19.Sporta politikas pamatnostadnes 2014.-2020. gadam. (2013). POLSIS: Politikas Planosanas Dokumentu datubaze. Retrieved from http://polsis.mk.gov.lv/documents/4599

20.Sports (2019). Latvia.eu. Available: http://www.latvia.eu/society/sports

21.Sports Law (2002). Latvijas Vestnesis, 165 (2740). 
22.Sports. (2019). Ministry of Education and Science. Available: https://www.izm.gov.Iv/en/sports-en

23. The legal system in Latvia (2016). Available: https://e-justice.europa.eu/content_

24. Veseligs dzivesveids (2014) DNB Latvijas barometrs. Available:

https://www.luminor.Iv/sites/default/files/docs/preses_relizes/dnb-latvijas-barometrs-petijums-nr69.pdf

25. What is Erasmus +. European Commission. Available: https://ec.europa.eu/programmes/erasmusplus/about_en

26. World Health Organisation (2009). World Health Statistics. Available:

http://www.who.int/whosis/whostat/EN_WHS09_Full.pdf?ua=1

27. Zalcmane K., Kamenecka-Usova M. (2018). The problematics of sports law in Latvia: civil and criminal law statutory acts perspective. Society. Integration. Education, Volume 4, pp. 332-346. 